\title{
Pengembangan modul pop-up berbasis inkuiri terbimbing pada tema tata surya untuk kelas VII SMP
}

\author{
Mia Novita Ningrum ${ }^{1}$, Novi Ratna Dewi ${ }^{1} *$, P. Parmin ${ }^{1}$ \\ Jurusan IPA Terpadu, Fakultas Matermatika dan Ilmu Pengetahuan Alam, Universitas Negeri \\ Semarang. Jl. Sekaran Raya, Sekaran, Gunung Pati, Semarang, Jawa Tengah, 50229, Indonesia \\ * Corresponding Author. Email: noviratnadewi@mail.unnes.ac.id \\ Received: 12 June 2017; Revised: 6 September 2017; Accepted: 15 February 2018
}

\begin{abstract}
Abstrak
Penelitian ini bertujuan untuk mengetahui kelayakan dan keefektifan modul pop-up berbasis inkuiri terbimbing tema tata surya. Penelitian ini merupakan penelitian pengembangan yang terdiri dari sepuluh langkah dalam pelaksanaannya. Modul yang dikembangkan kemudian divalidasi oleh 3 ahli materi dan 3 ahli media untuk mengetahui kelayakan produk. Hasil penelitian menunjukkan bahwa penilaian kelayakan modul pop-up berbasis inkuiri terbimbing oleh ahli materi dan media memperoleh skor rata-rata 54 dan 39 dengan kriteria sangat layak. Uji coba skala kecil untuk mengetahui keterbacaan modul mendapatkan rata-rata skor 36,89 dari siswa dan 11,9 dari guru dikategorikan sangat baik. Hasil skor N-gain diperoleh kriteria sedang sampai tinggi sebesar 93,75\% dan siswa mendapatkan nilai posttest $\geq 75$ sebesar $84,4 \%$. Berdasarkan hasil penelitian dapat disimpulkan bahwa modul pop-up berbasis inkuiri terbimbing tema tata surya layak dan efektif digunakan dalam proses pembelajaran.
\end{abstract}

Kata Kunci: Bahan ajar, modul pop-up, inkuiri terbimbing

\section{Development of pop-up module with inquiry guided-based in the solar system's theme for $7^{\text {th }}$ grade students}

\begin{abstract}
This research aims to determine the feasibility and effectiveness of pop-up module with the inquiry guided based in the solar system's theme. This research is a development research using research model that cited from Sugiyono (2015) which consists of ten steps in the implementation. Then, the modules which developed were validated by 3 material experts and 3 media experts to determine the feasibility of the product. The results show that the feasibility assessment of pop-up module with inquiry guided based is guided by material and the media experts obtain an average score of 54 and 39 with very reasonable criteria. Small-scale experiment aims to determine the legibility of the module earned an average score of 36.89 from students and 11.9 from teachers. The classical exhaustiveness obtained is $84,4 \%$, the average og gain normality is 0,55 with medium criterion. Based on the results of the research can be concluded that the pop-up module with inquiry guided-based in the solar system's theme is feasible and effective use in the learning process.
\end{abstract}

Keywords: teaching materials, pop-up module, quided inquiry

How to Cite: Ningrum, M., Dewi, N., \& Parmin, P. (2018). Pengembangan modul pop-up berbasis inkuiri terbimbing pada tema tata surya untuk kelas VII SMP. Jurnal Inovasi Pendidikan IPA, 4(1), 1-10. doi:http://dx.doi.org/10.21831/jipi.v4i1.14439

http://dx.doi.org/10.21831/jipi.v4i1.14439 


\section{PENDAHULUAN}

Bahan ajar adalah segala bahan (baik itu informasi, alat, maupun teks) yang disusun secara sistematis yang menampilkan sosok utuh dari kompetensi yang dikuasai peserta didik dan digunakan dalam proses pembelajaran dengan tujuan untuk perencanaan dan penelaahan implementasi pembelajaran (Prastowo, 2013, p. 138). Guru hendaknya mengembangkan bahan ajar sesuai dengan rencana pembelajaran.

Pengembangan bahan ajar oleh guru sudah diperjelas dalam Peraturan Menteri Pendidikan Nasional (Permendiknas) nomor 41 tahun 2007 tentang Standar Proses. Guru diharapkan untuk mengembangkan bahan ajar sebagai salah satu sumber belajar. Modul merupakan suatu bahan ajar yang disusun secara sistematis dengan menggunakan bahasa yang mudah dipahami oleh siswa sesuai dengan tingkat pengetahuan dan usianya agar mereka dapat belajar sendiri (mandiri) dengan bantuan atau bimbingan yang minimal dari guru (Prastowo, 2013, p. 209). Keberadaan modul saat ini masih verbal atau tekstual sehingga siswa masih merasa kurang tertarik untuk membacanya. Agar siswa mau membaca dan mudah memahaminya, perlu dikembangkan modul dengan disertai gambar atau ilustrasi. Sifatnya yang konkrit, media gambar atau ilustrasi lebih realistis menunjukkan pokok masalah dibandingkan dengan media verbal semata (Yusro \& Sasono, 2016). Media gambar atau ilustrasi dapat memperjelas penyampaian pesan dalam media verbal. Penggunaan ilustrasi yang dapat diterapkan di modul bisa dengan menambahkan gambar dalam bentuk 3 dimensi yang biasanya dikenal dengan istilah pop-up.

Pop-up merupakan suatu bentukan tiga dimensi yang dimanfaatkan untuk memperindah suatu buku maupun kartu ucapan (Dewantari, 2014). Hal menarik dari pop-up yaitu mampu memberikan hal-hal yang tidak terduga kepada orang yang membukanya. Buku-buku yang menyisipkan model pop-up mulai banyak dikembangkan guna meningkatkan minat baca pada anak-anak. Amerika Serikat telah mencoba mengembangkan dan menerapkan buku dengan model pop-up. Buku berisi tampilan halamanhalaman berisi informasi dalam bentuk 3 dimensi dan dapat digerakkan pada saat membuka lembaran buku pop-up agar tidak membosankan pembaca (Hawarya \& Warso, 2014). Wulandari (2015) menyatakan bahwa pemanfaatan modul berbentuk pop-up dan smash book layak, praktis, dan efektif digunakan dalam pembelajaran materi sistem reproduksi manusia. Sehingga pemanfaatan modul pop-up dalam pembelajaran memungkinkan diterapkan.

Pembelajaran IPA SMP pada materi tata surya di SMP Negeri 2 Magelang masih bersifat tekstual yang mengandalkan kepada buku paket yang berisi materi dan soal-soal. Dibutuhkan pembelajaran dimana siswa diberi suatu masalah-masalah untuk diselidiki menggunakan caracara keterampilan ilmiah dalam rangka mencari penjelasan-penjelasannya. Model inkuiri sangat erat dalam pembelajaran IPA (Maharani \& Dewi, 2015). Pembelajaran inkuiri yang cocok diterapkan pada anak SMP adalah inkuiri terbimbing (Astuti \& Setiawan, 2013). Model pembelajaran yang bisa memunculkan keterampilan ilmiah adalah model penemuan terbimbing (Rahayu, Widiyatmoko, \& Dewi, 2016). Siswa merencanakan prosedurnya sendiri untuk memecahkan masalah. Guru memfasilitasi penyelidikan dan mendorong siswa mengungkapkan atau membuat pertanyaan-pertanyaan yang membimbing mereka untuk penyelidikan lebih lanjut. Pendekatan ini siswa lebih berorientasi pada bimbingan dan petunjuk dari guru hingga siswa dapat memahami konsep-konsep pelajaran (Matthew \& Kenneth, 2013).

Pendekatan inkuiri terbimbing ini digunakan bagi siswa yang kurang berpengalaman belajar dengan pendekatan inkuiri (Villagonzalo, 2014). Suprihatin \& Hidayah (2014) menyatakan model pembelajaran inkuiri terbimbing dapat meningkatkan dalam melatih keterampilan menyelesaikan masalah pada materi pencemaran lingkungan. Pembelajaran inkuiri terbimbing dapat membantu siswa memecahkan masalah yang terdapat dalam modul pop-up. Pendekatan inkuiri terbimbing yang digunakan dalam modul pop-up yaitu sesuai sintaks model pembelajaran inkuri terbimbing yang dikemukakan oleh Gulo, sebagaimana dikutip oleh Trianto (2007, p. 137). Sintaks model pembelajaran inkuiri terbimbing meliputi menyajikan masalah, merumuskan hipotesis, mengumpulkan data, analisis data dan membuat kesimpulan. Siswa memiliki keingintahuan dan ingin berkembang. Inkuiri terbimbing menekankan pada pemberian kesempatan pada siswa untuk bereksplorasi dan memberikan arah yang spesifik sehingga area-area baru dapat tereksplorasi dengan lebih baik (Kuhlthau, Maniotes, \& Caspari, 2007).

Sintaks model pembelajaran inkuiri terbimbing akan dimasukkan dalam modul pop-up. 
Produk yang dikembangkan dapat digunakan untuk mengukur atau mengevaluasi hasil belajar siswa. Produk yang dikembangkan di dalamnya terdapat gambar yang berbentuk 3 dimensi yang dapat memperjelas isi produk dan membuat lebih menarik. Sesuai dengan masalah dan latar belakang yang telah diuraikan, perlu dilakukan penelitian dengan judul "Pengembangan Modul Pop-Up Berbasis Inkuiri Terbimbing pada Tema Tata Surya untuk Kelas VII SMP”.

\section{METODE}

Penelitian ini merupakan penelitian pengembangan menggunakan model penelitian yang dikutip dari Sugiyono (2015), yaitu ada sepuluh langkah dalam pelaksanaan strategi penelitian dan pengembangan. Langkah-langkah penelitian dan pengembangan produk dijelaskan sebagai berikut:

Pertama, Potensi dan Masalah. Tahap ini meliputi kegiatan wawancara dengan siswa dan guru mata pelajaran IPA di SMP Negeri 2 Magelang dan melakukan kegiatan observasi.

Kedua, Pengumpulan data. Tahap ini meliputi perangkat pembelajaran dan penggunaan bahan ajar, kebutuhan akan bahan ajar, dan analisis kekurangan bahan ajar yang digunakan serta nantinya dijadikan bahan kajian dalam pengembangan.

Ketiga, Desain produk modul pop-up berbasis inkuiri terbimbing meliputi penyusunan pokok materi, penyusunan naskah secara keseluruhan, pembuatan modul pop-up berbasis inkuiri terbimbing dan editing. Keempat, Validasi desain. Tahap ini meliputi validasi ahli materi dan media.

Kelima, Revisi desain media. Tahap ini meliputi penyempurnaan produk sesuai saran ahli. Keenam, Uji coba skala kecil. Tahap ini meliputi kegiatan penggunaan modul dalam skala kecil bertujuan mengetahui keterbacaan modul. Keterbacan modul diisi oleh 10 siswa kelas VIII C dan 3 guru IPA SMP Negeri 2 Magelang. Ketujuh, Revisi hasil uji coba. Tahap ini meliputi penyempurnaan produk berdasarkan hasil angket keterbacaan. Kedelapan, Uji coba skala besar. Menerapkan pembelajaran proses pembelajaran berdasarkan RPP yang telah disusun. Soal pretest diberikan sebelum pembelajaran dan soal posttest diberikan berguna untuk mengetahui keefektifan modul yang dikembang- kan. Tahap ini juga dilakukan pembagian angket pemakaian modul bertujuan untuk mengetahui pemakaian modul.

Kesembilan, Revisi produk. Tahap ini meliputi penyempurnaan produk berdasarkan uji coba skala besar. Kesepuluh, Produk akhir dari penelitian pengembangan ini adalah modul popup berbasis inkuiri terbimbing pada tema tata surya yang layak dan efektif digunakan sebagai bahan ajar.

Metode pengumpulan data yang digunakan adalah angket dan tes. Metode analisis data dalam penelitian ini meliputi : lembar validasi kelayakan materi dan media, angket keterbacaan modul dari siswa dan guru, angket pemakaian, hasil peningkatan pretest dan posttest. Rumus peningkatan tes sebagai berikut:

$$
N-\text { gain }=\frac{\text { skor posttest }- \text { skor pretest }}{\text { skor maksimal }- \text { skor pretest }}
$$

Keterangan:

$\mathrm{N}$-gain = besarnya faktor gain

Skor posttest $=$ nilai hasil tes akhir

Skor pretest = nilai tes awal

Skor maksimal $=$ nilai maksimal tes

\section{HASIL DAN PEMBAHASAN}

Penilaian kelayakan modul merupakan kegiatan untuk menilai apakah modul yang telah dikembangkan layak untuk digunakan atau tidak. Penilaian kelayakan modul dilakukan dengan cara memberikan modul kepada ahli materi, media dan disertakan lembar validasi. Proses validasi modul dilakukan dengan tujuan untuk memperbaiki modul berdasarkan penilaian ahli berupa cheklist dan komentar atau saran yang menghasilkan modul yang layak digunakan sebagai bahan ajar. Penilaian modul terdiri atas dua komponen yaitu kelayakan materi dan kelayakan media. Penilaian dinilai oleh 6 ahli yaitu (2 dosen pendidikan IPA Unnes dan 4 guru SMP N 2 Magelang).

Komponen penilaian kelayakan materi dikembangkan dengan menyertakan aspek penilaian tentang inkuiri terbimbing. Penilaian kelayakan komponen dijabarkan dalam empat belas indikator. Hasil penilaian ahli materi disajikan pada Tabel 1. 
Jurnal Inovasi Pendidikan IPA, 4 (1), 2018 - 4

Mia Novita Ningrum, Novi Ratna Dewi, P. Parmin

Tabel 1. Hasil Penilaian Kelayakan Modul oleh Ahli Materi

\begin{tabular}{|c|c|c|c|c|}
\hline \multirow{2}{*}{ No. } & \multirow{2}{*}{ Validator } & \multirow{2}{*}{ Instansi } & \multicolumn{2}{|c|}{ Skor (\%) } \\
\hline & & & Validasi I & Validasi II \\
\hline 1. & Validator I & Dosen Pendidikan IPA & $\begin{array}{c}75 \\
\text { (Layak) }\end{array}$ & $\begin{array}{c}98 \\
\text { (Sangat Layak) }\end{array}$ \\
\hline 2. & Validator II & Guru IPA SMP N 2 Magelang & $\begin{array}{c}91 \\
\text { (Sangat Layak) }\end{array}$ & $\begin{array}{c}91 \\
\text { (Sangat Layak) }\end{array}$ \\
\hline 3. & Validator III & Guru IPA SMP N 2 Magelang & $\begin{array}{c}91 \\
\text { (Sangat Layak) }\end{array}$ & $\begin{array}{c}100 \\
\text { (Sangat Layak) }\end{array}$ \\
\hline & & Rata-rata skor & $\begin{array}{c}86 \\
\text { (Sangat Layak) }\end{array}$ & $\begin{array}{c}96 \\
\text { (Sangat Layak) }\end{array}$ \\
\hline
\end{tabular}

Berdasarkan Tabel 1 penilaian kelayakan modul aspek materi skor yang diberikan ahli materi II dan III (Guru IPA) lebih tinggi dibandingkan dengan skor yang diberikan ahli materi I (Dosen IPA) pada tahap validasi I. Hasil skor penilaian ini dikarenakan skor yang diberikan dalam komponen (1) contoh dan kasus aktual yaitu latihan soal, uji kompetensi belum mencakup tingkatan taksonomi Bloom, soal masih banyak $\mathrm{C} 1$ yaitu mengingat atau menghafal tingkatan terlalu mudah untuk sebuah modul; (2) gambar, diagram, dan ilustrasi aktual yaitu gambar pop-up yang disajikan menghalangi pembaca untuk belajar memahami isi modul; (3) mengumpulkan data, yaitu bahwa sintaks inkuiri terbimbing yang terdapat dalam modul belum terlihat secara jelas, sehingga memperoleh skor yang minimal dan skor yang diperoleh menjadi lebih sedikit.

Penilaian tahap I banyak mendapatkan saran dan masukan dari ahli materi sehingga dilakukan revisi terkait 3 komponen tersebut. Revisi yang dilakukan pada ketiga komponen yaitu (1) contoh dan kasus aktual yaitu latihan soal pada kegiatan 1, 2 dan uji kompetensi. Setiap indikator soal mempunyai penekanan kemampuan yang berbeda-beda, karena itu aspek yang diujipun haruslah yang berbeda pula. Sehingga soal dalam modul tidak hanya $\mathrm{C} 1$ tetapi soal sudah mencakup tingkatan soal kognitif taksonomi Bloom; (2) komponen gambar, diagram, dan ilustrasi aktual sudah dilakukan revisi dengan menempatkan gambar pop-up di dalam satu halaman kosong yang tidak terdapat tulisan, kegiatan I gambar yang dibuat menjadi pop-up adalah tata surya (terdiri Matahari dan ke delapan planet yang mengitarinya). Sedangkan, kegiatan II gambar yang dibuat pop-up adalah fase-fase Bulan. (3) mengumpulkan data, menambahkan kalimat yang menuntun siswa dapat mengerjakan modul sesuai dengan langkah inkuiri terbimbing. sebelum revisi "untuk menguji hipotesis yang kalian miliki, lakukan kegiatan mari melakukan di bawah ini" setelah revisi "Dugaan sementara (hipotesis) yang telah kalian ajukan perlu diuji kebenaranya dengan melakukan kegiatan "orbital planet". Cermati dan pahami setiap langkah kegiatan dan jawab setiap pertanyaan yang ada sebagai analisis data".

Modul yang telah direvisi kemudian dinilai kembali. Pada penilaian kelayakan materi yang kedua merujuk Tabel 1 semua butir aspek mendapat nilai $\geq 3$ dari rentang 1 sampai 4 . Penilaian kelayakan materi yang kedua memperoleh skor rata-rata 54. Berdasarkan hasil penilaian, dapat diketahui bahwa keseluruhan komponen kelayakan materi yang dinilai oleh ahli materi menunjukkan sangat baik. Sehingga, dapat diambil kesimpulan bahwa komponen kelayakan materi modul pop-up berbasis inkuiri terbimbing dinyatakan sangat layak ditinjau dari aspek keluasan materi, kedalaman materi, akurasi fakta, akurasi konsep atau hukum atau teori, akurasi prosedur atau metode, kesesuaian dengan perkembangan ilmu, contoh dan kasus aktual gambar, diagram dan ilustrasi aktual, mendorong rasa ingin tahu, menyajikan masalah, menyusun hipotesis, mengumpulkan data, analisis data, dan membuat kesimpulan.

Hasil rekapitulasi penilaian kelayakan modul oleh ahli materi mendapat skor tinggi pada komponen wawasan inkuiri terbimbing. Modul yang dikembangkan dengan berbasis inkuiri terbimbing dapat meningkatkan sikap ilmiah siswa dan pemahaman konsep, hal ini sesuai dengan penelitian yang dilakukan Margiastuti, Parmin, \& Pamelasari (2015) menyatakan bahwa penerapan model guided inquiry efektif untuk meningkatkan pemahaman konsep siswa dan terdapat perbedaan sikap ilmiah siswa pada kelas eksperimen dan kelas kontrol. Penilaian kelayakan materi juga mendapat respon positif dari ahli materi. 
Jurnal Inovasi Pendidikan IPA, 4 (1), 2018 - 5

Mia Novita Ningrum, Novi Ratna Dewi, P. Parmin

Tabel 2. Hasil Penilaian Kelayakan Modul oleh Ahli Media

\begin{tabular}{|c|c|c|c|c|}
\hline \multirow{2}{*}{ No. } & \multirow{2}{*}{ Validator } & \multirow{2}{*}{ Instansi } & \multicolumn{2}{|c|}{ Skor (\%) } \\
\hline & & & Validasi I & Validasi II \\
\hline 1. & Validator 1 & Dosen Pendidikan IPA & $\begin{array}{c}50 \\
\text { (cukun lavak) }\end{array}$ & $\begin{array}{c}95 \\
\text { (sangat lavak) }\end{array}$ \\
\hline 2. & Validator II & Guru IPA SMP N 2 Magelang & $\begin{array}{c}88 \\
\text { (sangat layak) }\end{array}$ & $\begin{array}{c}98 \\
\text { (sangat layak) }\end{array}$ \\
\hline 3. & Validator III & Guru IPA SMP N 2 Magelang & $\begin{array}{c}90 \\
\text { (sangat layak) }\end{array}$ & $\begin{array}{c}100 \\
\text { (sangat layak) }\end{array}$ \\
\hline & & Rata-rata skor & $\begin{array}{c}75 \\
\text { (layak) }\end{array}$ & $\begin{array}{c}98 \\
\text { (sangat layak) }\end{array}$ \\
\hline
\end{tabular}

Berdasarkan Tabel 2 oleh ahli media II dan III (Guru IPA) lebih tinggi dibandingkan dengan skor yang diberikan ahli media I (Dosen IPA) pada tahap validasi I. Hasil skor penilaian ini dikarenakan skor yang diberikan dalam komponen tampilan yaitu; (1) kemenarikan tampilan, tampilan modul belum menarik masih belum menimbulkan minat untuk dilihat bahkan digunakan karena penempatan gambar pop-up masih menggangu pembaca modul; (2) pemilihan dan keserasian warna, pemilihan gambar popup masih banyak yang sangat menggangu pembaca.

Mengenai kelayakan, (3) kualitas gambar, gambar yang ditampilkan belum jelas karena mendownload menggunakan resolusi rendah di setiap gambar; (4) kualitas cetakan, gambar popup di dalam modul masih sangat rendah karena masih menggunakan kertas hvs yang tipis dan cepat rusak atau tidak awet; (5) unsur kelengkapan identitas, sudah lengkap tetapi masih ada sub BAB judul yang ukurannya tidak sama; (6) ukuran gambar, perbandingan ukuran gambar pop-up (Planet-planet, Matahari) tidak sesuai dengan perbandingan ukuran aslinya; (7) keinovatifan, sudah cukup kreatif tetapi gambar pop-up masih belum layak digunakan dalam pembelajaran; (8) jenis ukuran dan warna huruf, jenis huruf yang sangat monoton, ukuran huruf yang masih belum sama antara satu dengan yang lainnya; (9) unsur tata letak, letak pop-up yang mengganggu pembaca saat membacanya; (10) topografi isi, masih banyak huruf yang bervariasi, spasi antar huruf yang tidak sama.

Penilaian tahap I banyak mendapatkan saran dan masukan dari ahli media sehingga dilakukan revisi ke validasi tahap II. Revisi yang dilakukan pada ketiga komponen yaitu (1) saran dari ahli media kebanyakan mengenai gambar pop-up. Oleh karena itu, dilakukan revisi terkait gambar pop-up yaitu menempatkan modul di halaman tersendiri sehingga tidak mengganggu pembaca, mendownload gambar pop-up dengan resolusi yang tinggi sehingga menghasilkan gambar yang tidak blur, mencetak gambar popup menggunakan kertas yang lebih tebal sehingga lebih awet dan tidak cepat sobek yaitu menggunakan kertas hvs untuk gambar pop-up, merevisi perbandingan ukuran gambar pop-up seperti perbandingan antara Matahari dengan planet-planet lainnya. (2) merevisi jenis huruf pada modul dengan jenis Leelawadee dan Berlin Sans FB, mengatur jarak antar spasi agar sama.

Modul yang telah direvisi kemudian dinilai kembali. Pada penilaian kelayakan media yang kedua semua butir aspek mendapat nilai $\geq$ 3 dari rentang 1 sampai 4. Penilaian kelayakan media yang kedua memperoleh skor rata-rata 39. Berdasarkan hasil penilaian, dapat diketahui bahwa keseluruhan komponen kelayakan media yang dinilai oleh ahli media menunjukkan sangat baik. Sehingga, dapat diambil kesimpulan bahwa komponen kelayakan media modul popup berbasis inkuiri terbimbing dinyatakan sangat layak ditinjau dari aspek kemenarikan tampilan, pemilihan dan keserasian warna, kualitas gambar, kualitas cetakan, unsur kelengkapan identitas, ukuran gambar, keinovatifan, jenis ukuran dan warna huruf, unsur tata letak, dan topografi isi.

Hasil penilaian ahli media menekankan pada gambar pop-up yang digunakan. Penggunaan pop-up di dalam modul mampu meningkatkan keantusiasan siswa dalam proses pembelajaran menggunakan modul. Pernyataan tersebut sesuai dengan penelitian yang dilakukan oleh Febrianto, Setiadarma, \& Aryanto (2014) menyatakan bahwa penerapan pop-up book dapat mempermudah guru dalam menyampaikan materi dan memudahkan siswa memahami materi, di samping itu penerapan pop-up book juga mampu untuk meningkatkan keantusiasan siswa dalam proses belajar dan kreativitas siswa dalam berkarya.

Penilaian kelayakan oleh ahli materi dan media terdapat beberapa saran perbaikan 
sehingga dilakukan revisi sesuai hasil penilaian kelayakan oleh ahli yang telah dilakukan. Selanjutnya modul dinyatakan "sangat layak". Hasil penelitian ini hampir serupa dengan penelitian yang dilakukan oleh Setyowati, Parmin, \& Widiyatmoko (2013) tahap validasi produk dilakukan oleh ahli materi dan ahli media dilakukan oleh guru IPA. Berdasarkan hasil validasi produk tersebut modul dapat dikatakan sangat baik setelah melakukan revisi dan perbaikan sesuai saran yang diberikan oleh ahli materi dan desain.

Berdasarkan hasil penilaian dapat diketahui bahwa keseluruhan komponen modul yang dinilai oleh ahli menunjukkan hasil sangat baik. Sehingga, dapat diambil kesimpulan bahwa modul pop-up berbasis inkuiri terbimbing dinyatakan layak dan dapat diuji ketahap selanjutnya. Modul yang telah dinyatakan layak, selanjutnya diuji cobakan untuk mengetahui tingkat keterbacaan modul. Hasil keterbacaan modul oleh guru dapat dilihat pada Tabel 3.

Tabel 3. Hasil Angket Tanggapan Guru

\begin{tabular}{|c|c|c|c|}
\hline No. & Aspek yang ditanyakan & $\begin{array}{l}\text { Skor } \\
(\%)\end{array}$ & Kriteria \\
\hline 1. & $\begin{array}{l}\text { Materi yang disajikan sesuai } \\
\text { dengan KI dan KD }\end{array}$ & 100 & $\begin{array}{l}\text { Sangat } \\
\text { baik }\end{array}$ \\
\hline 2. & $\begin{array}{l}\text { Materi dalam modul sesuai } \\
\text { dengan IPTEK }\end{array}$ & 100 & $\begin{array}{l}\text { Sangat } \\
\text { baik }\end{array}$ \\
\hline 3. & $\begin{array}{l}\text { Materi dalam modul sesuai } \\
\text { dengan karakteristik } \\
\text { lingkungan }\end{array}$ & 92 & $\begin{array}{l}\text { Sangat } \\
\text { baik }\end{array}$ \\
\hline 4. & $\begin{array}{l}\text { Tujuan pembelajaran } \\
\text { dirumuskan seara jelas dan } \\
\text { sesuai indikator }\end{array}$ & 100 & $\begin{array}{l}\text { Sangat } \\
\text { baik }\end{array}$ \\
\hline 5. & $\begin{array}{l}\text { Penyajian materi dapat } \\
\text { mengaktifkan siswa }\end{array}$ & 100 & $\begin{array}{l}\text { Sangat } \\
\text { baik }\end{array}$ \\
\hline 6. & $\begin{array}{l}\text { Konsep dalam modul } \\
\text { disajikan secara sistematis }\end{array}$ & 100 & $\begin{array}{l}\text { Sangat } \\
\text { baik }\end{array}$ \\
\hline 7. & $\begin{array}{l}\text { Penyajian materi } \\
\text { memungkinkan siswa untuk } \\
\text { berinteraksi dengan } \\
\text { lingkungan }\end{array}$ & 100 & $\begin{array}{l}\text { Sangat } \\
\text { baik }\end{array}$ \\
\hline 8. & $\begin{array}{l}\text { Penyajian materi pada } \\
\text { modul tidak menuntut } \\
\text { banyak penjelasan dari guru }\end{array}$ & 100 & $\begin{array}{l}\text { Sangat } \\
\text { baik }\end{array}$ \\
\hline 9. & $\begin{array}{l}\text { Menggunakan kombinasi } \\
\text { warna dan gambar }\end{array}$ & 100 & $\begin{array}{l}\text { Sangat } \\
\text { baik }\end{array}$ \\
\hline 10. & $\begin{array}{l}\text { Penggunaan bahasanya } \\
\text { sederhana }\end{array}$ & 100 & $\begin{array}{c}\text { Sangat } \\
\text { baik }\end{array}$ \\
\hline & Skor rata-rata & 99 & $\begin{array}{l}\text { Sangat } \\
\text { baik }\end{array}$ \\
\hline
\end{tabular}

Berdasarkan hasil keterbacaan modul yang disajikan pada Tabel 3 menunjukkan bahwa skor rata-rata yaitu $99 \%$ dikategorikan sangat baik. Keterbacaan modul juga dianalisis berdasarkan tanggapan dari guru.

Guru memberikan tanggapan terhadap modul yang telah dikembangkan. Data keterbacaan modul oleh guru diperoleh dengan cara memberikan instrumen penilaian terhadap guru. Guru kemudian memberikan penilaian dengan cara mengisi angket yang telah disediakan. Berdasarkan Tabel 4 materi yang disajikan sesuai dengan $\mathrm{KI}$ dan $\mathrm{KD}$, hal ini sesuai dengan hasil penilaian dari ahli materi yang menyatakan penyajian materi telah mencerminkan jabaran pada KI 3 dengan KD 3.11. Materi yang disajikan dalam modul cukup sesuai dengan perkembangan IPTEK.

Tanggapan tersebut sesuai dengan hasil penilaian ahli yang menyatakan materi yang terdapat dalam modul sesuai dengan perkembangan kelimuan terkini. Tanggapan dari guru juga menyatakan bahwa konsep yang ada dalam modul sesuai dengan karakteristik lingkungan. Tujuan pembelajaran sudah lebih dari $75 \%$ selaras dengan indikator. Materi yang disajikan dalam modul cukup dapat membuat siswa aktif selama pembelajaran. Konsep yang disajikan dalam modul sudah sistematis.

Penyajian materi memungkinkan siswa untuk berinteraksi dengan lingkungan. Penyajian materi dalam modul memungkinkan siswa berinteraksi dengan lingkungan. Sesuai dengan hasil penilaian ahli materi menyatakan bahwa modul terdapat contoh-contoh yang dapat menghubungkan pengetahuan siswa dengan kehidupan sehari-hari. Penyajian materi dalam modul tidak menjadikan guru dominan dalam pembelajaran, hal ini sesuai dengan hasil penilaian ahli materi yaitu modul mendorong rasa ingin tahu siswa dengan mengerjakan latihan soal-soal, mengisi bagian yang kosong dalam modul.

Penggunaan warna dan gambar pada modul menarik, hal ini sesuai dengan penilain ahli media yang menyatakan bahwa warna tulisan dengan background serasi, tulisan dapat terbaca dengan jelas, gambar yang ditampilkan jelas (tidak hablur/kabur), dan gambar fokus pada objek. Berdasarkan hasil tanggapan guru yang diperoleh modul dikategorikan sangat baik, dan dapat diinterpretasikan bahwa semua responden bisa memahami materi.

Guru juga menyarankan untuk bisa mengembangkan modul pada materi IPA lainnya agar bisa banyak memberikan wawasan yang luas bagi siswa supaya lebih memahami tentang materi IPA dan menumbuhkan keaktifan 
Jurnal Inovasi Pendidikan IPA, 4 (1), 2018 - 7

Mia Novita Ningrum, Novi Ratna Dewi, P. Parmin

siswa dalam pembelajaran. Secara keseluruhan modul pop-up berbasis inkuiri terbimbing tema tata surya di kategorikan sangat baik ditinjau dari aspek materi yang disajikan sesuai dengan $\mathrm{KI}$ dan KD, materi dalam modul sesuai dengan IPTEK, materi dalam modul sesuai dengan karakteristik lingkungan, tujuan pembelajaran dirumuskan seara jelas dan sesuai indikator, penyajian materi dapat mengaktifkan siswa, konsep dalam modul disajikan secara sistematis, penyajian materi memungkinkan siswa untuk berinteraksi dengan lingkungan, penyajian materi pada modul tidak menuntut banyak penjelasan dari guru, menggunakan kombinasi warna dan gambar, dan penggunaan bahasanya sederhana.

Uji coba skala kecil dilakukan untuk mengetahui keterbacaan modul sebelum diujikan pada uji coba skala besar. Selain untuk mengetahui tingkat keterbacaan modul, uji coba modul juga digunakan untuk mengetahui keefektifan modul dalam peningkatan hasil belajar. Data hasil belajar diperoleh dari uji coba modul skala besar. Modul yang sudah di uji coba skala kecil, kemudian di uji coba skala besar di kelas VII C SMP Negeri 2 Magelang sejumlah 32 siswa. uji coba skala besar bertujuan mengetahui keefektifan modul. Keefektifan modul diketahui dari peningkatan hasil belajar siswa setelah menggunakan modul dari nilai pretest dan posttest. Peningkatan hasil belajar dianalisis menggunakan rumus $\mathrm{N}$-gain. Hasil perhitungan didapatkan skor $\mathrm{N}$-gain sebesar 0,55 yang masuk dalam kategori sedang.

Capaian persentase hasil perhitungan $\mathrm{N}$ gain disajikan pada Tabel 4 .
Tabel 4. Rekapitulasi Hasil Perhitungan N-Gain

\begin{tabular}{ccc}
\hline No. & Kriteria & Persentase N-gain \\
\hline 1. & Sedang & $65,625 \%$ \\
2. & Tinggi & $28,125 \%$ \\
3. & Rendah & $6,25 \%$ \\
\hline
\end{tabular}

Berdasarkan Tabel 4 persentase N-gain dengan kriteria sedang sampai tinggi sebesar $93,75 \%$ dan siswa mendapatkan nilai posttest lebih besar sama dengan 75 sebesar 84,375\%. Selain hasil tes selama uji coba skala besar diberikan angket pemakaian modul untuk mengetahui pemakaian modul skala besar. Hasil pemakaian modul disajikan Tabel 5.

Modul pop-up berbasis inkuiri terbimbing tema tata surya efektif digunakan karena beberapa hal. Pertama, berkenaan dengan modul yang digunakan. Berdasarkan Tabel 5 siswa merasa tertarik dan senang belajar dengan adanya modul sebagai bahan ajar karena tampilan pop-up yang membuat modul menarik. Membaca salah satu bentuk motivasi belajar siswa.

Motivasi dapat dibangun dari keingintahuan siswa mencoba untuk menemukan, mencari dan menyelidiki apa yang mereka belum tahu. Modul juga membantu siswa dalam pemahaman materi yang disampaikan karena modul menggunakan bahasa yang mudah dipahami. Modul yang diberikan pada siswa menuntut sisa untuk mengisi bagian-bagian modul yang kosong, mengerjakan soal-soal latihan yang ada, menandai bagian-bagian yang penting dan menanyakan hal-hal yang belum di mengerti sehingga dengan cara seperti itu siswa akan termotivasi mempelajari modul.

Tabel 6. Hasil Angket Pemakaian Modul oleh Siswa

\begin{tabular}{clcc}
\hline No. & \multicolumn{1}{c}{ Aspek yang ditanyakan } & $\begin{array}{c}\text { Skor } \\
\text { (skor maksimal = 128) }\end{array}$ & Kriteria \\
\hline 1. & Senang menggunakan modul sebagai bahan ajar & 122 & Sangat baik \\
2. & Tampilan yang menarik & 123 & Sangat baik \\
3. & Meningkatkan motivasi dalam belajar materi tata surya & 119 & Sangat baik \\
4. & Materi mudah dipahami & 120 & Sangat baik \\
5. & Bahasa mudah dipahami & 120 & Sangat baik \\
6. & Tulisan dapat dibaca dengan jelas & 125 & Sangat baik \\
7. & Gambar pendukung dan tulisan membantu memahami materi & 125 & Sangat baik \\
8. & Proposi gambar dan tulisan seimbang & 119 & Sangat baik \\
9. & Memahami $\geq 75 \%$ materi & 117 & Sangat baik \\
10. & Terbantu memahami materi tata surya & 122 & Sangat baik \\
11. & Soal-soal latihan variatif sehingga tertarik untuk mengerjakanya & 117 & Sangat baik \\
12. & Soal-soal latihan membantu pemahaman terhadap materi & 119 & Sangat baik \\
\hline \multicolumn{2}{r}{ Skor rata-rata } & 120,67 & Sangat baik \\
\hline
\end{tabular}


Jurnal Inovasi Pendidikan IPA, 4 (1), 2018 - 8

Mia Novita Ningrum, Novi Ratna Dewi, P. Parmin

Kedua, berkenaan dengan penggunaan рор-ир di dalam modul proporsi gambar pop-up sesuai dengan perbandingan aslinya, sehingga memiliki daya tarik sendiri dalam proses pembelajaran karena dapat memvisualisasikan materi tata surya. Hal ini sesuai dengan penelitian Nancy dan Rondha yang dikutip oleh Khoirotun, Fianto, \& Riqqoh (2014) mengemukakan bahwa buku pop-up dianggap mempunyai daya tarik tersendiri bagi remaja yaitu dengan menyajikan visualisasi dalam bentuk-bentuk yang dibuat melipat dan sebagainya.

Ketiga, berkenaan dengan pendekatan modul yang digunakan yaitu inkuiri terbimbing. Metode inkuiri terbimbing siswa akan dihadapkan pada tugas-tugas yang relevan untuk diselesaikan baik melalui diskusi kelompok maupun secara individual agar mampu menyelesaikan masalah dan menarik suatu kesimpulan secara mandiri (Douglas \& Chiu, 2009). Modul berbasis inkuiri terbimbing menyebabkan siswa aktif dan berperan sebagai subjek pembelajaran. Pertanyaan-pertanyaan pancingan yang disajikan dalam modul membuat siswa memiliki rasa ingin tahu, sehingga menumbuhkan motivasi belajar pada diri siswa. Alasan tersebut sejalan dengan penelitian Agustanti (2012) bahwa dengan pendekatan inkuiri siswa menjadi lebih aktif dan berpartisipasi dalam kegiatan pembelajaran.

Keaktifan saat proses pembelajaran ditunjukkan dengan semangatnya siswa untuk menanyakan hal-hal yang belum diketahui dari modul, mengisi bagian-bagian yang kosong. Proses pembelajaran dilakukan siswa dengan senang dan menanyakan maksud setiap langkahlangkah inkuiri yang belum diketahui. Kegiatan mengisi modul berlangsung melakukan percobaan sederhana di dalamnya siswa mendapatkan pengetahuan secara langsung sesuai apa yang mereka amati. Siswa aktif dalam pembelajaran berarti siswa berperan sebagai subjek pembelajaran dan mendapatkan pengetahuan dengan pengamatan langsung.

Hasil analisis terdapat hubungan yang positif antara pertanyaan-pertanyaan dalam modul sesuai sintaks inkuri terbimbing terhadap rasa ingin tahu siswa tentang hal-hal lain yang berkaitan, sehingga mendorong siswa untuk aktif mencari tahu salah satunya bertanya. Hasil analisis ini sesuai dengan penelitian Wenning (2011) menunjukkan bahwa inkuiri adalah sebuah pendekatan pembelajaran yang menekankan pada keaktifan siswa sehingga siswa bertindak sebagai subjek pembelajaran secara penuh di dalam kelas.

Dua siswa dalam penelitian ini masih mempunyai nilai gain rendah. Rendahnya nilai gain dapat disebabkan siswa pertama mendapatkan nilai pretest siswa memang sudah tinggi sehingga modul tidak berpengaruh besar pada posttest siswa. Kondisi ini dapat dialami oleh siswa yang memang dari awalnya memiliki kecerdasan yang tinggi. Sebaliknya siswa kedua mendapatkan nilai pretest dan posttest yang rendah sehingga tidak terjadi peningkatan yang signifikan. Berdasarkan analisis tersebut berarti modul tidak berpengaruh dan tidak efektif digunakan untuk kedua siswa tersebut.

Siswa mendapatkan nilai posttest $\geq 75$ sebesar $84,4 \%$ menunjukkan bahwa pengembangan modul pop-up berbasis inkuiri terbimbing dinyatakan efektif. Hal ini di dukung oleh penelitian Ikhsan, Sutarno, \& Prayitno (2016) menunjukkan bahwa pengembangan modul berbasis inkuiri terbimbing pada materi sistem gerak manusia untuk meningkatkan hasil belajar siswa kelas XI MIA SMA Negeri 1 Wera Kabupaten Bima Nusa Tenggara Barat layak digunakan dengan kategori sangat baik 95,83\% dan efektif untuk meningkatkan hasil belajar siswa selama pembelajaran dengan menggunakan modul.

Penggunaan modul dalam pembelajaran IPA membantu proses pembelajaran. Pengembangan modul dalam pembelajaran harus memenuhi kriteria kelayakan oleh ahli materi dan media. Hasil penilitian mengenai pengembangan modul menunjukkan hasil penelitian Muhafid, Dewi, \& Widiyatmoko (2013) menunjukkan bahwa pengembangan modul untuk kelas VIII memenuhi aspek kelayakan sesuai dengan kriteria penilaian bahan ajar dan efektif digunakan dalam pembelajaran siswa SMP kelas VIII.

Pendekatan inkuiri terbimbing yang digunakan dalam modul meningkatkan hasil belajar siswa dibandingkan pembelajaran konvensional, hal ini sejalan dengan penelitian Dewi, Dantes, \& Sadia (2013) yang menyatakan bahwa hasil belajar menggunakan model inkuiri terbimbing lebih baik dari model konvensional sebab siswa memperoleh pengetahuan sendiri melalui pengalaman secara langsung. Selain itu, menurut Wening sebagaimana dikutip Parmin \& Peniati (2012) efisiensi modul juga berdasarkan biaya penggandaan yang terjangkau, sedangkan kelayakan ditentukan dari sistematika penulisan modul yang mudah dipahami, materi relevan 
dengan kompetensi yang diukur dan rujukan yang digunakan mutakhir.

Berdasarkan hasil penelitian, dapat diketahui modul pop-up berbasis inkuiri terbimbing pada tema tata surya untuk kelas VII SMP mempunyai kelebihan yaitu: (1) berisi pop-up yang dapat memperjelas isi modul dan tampilannya menarik, (2) membuat modul yang menyenangkan yang mengundang minat baca siswa dan termotivasi mengikuti pembelajaran (3) modul yang membantu siswa menemukan atau menyelidiki konsep atau materi yang dipelajari sesuai sintaks inkuiri terbimbing, dan (4) mampu mengubah model pembelajaran berupa transfer infomasi dari guru menjadi pembelajaran bermakna, yakni siswa menemukan sendiri apa yang dipelajari melalui modul.

\section{SIMPULAN}

Simpulan dari hasil penelitian ini, yaitu modul pop-up berbasis inkuiri terbimbing tema tata surya layak digunakan dengan skor rata-rata ahli materi dan media sebesar $96 \%$ dan $98 \%$ dengan kriteria sangat layak. Berdasarkan skor $\mathrm{N}$-gain $(0,55)$ dengan kriteria sedang, terdapat 93,75\% siswa masuk dalam kategori sedang sampai tinggi dan siswa mendapatkan nilai posttest $\geq 75$ sebesar $84,4 \%$, sehingga modul pop-up berbasis inkuiri terbimbing pada tema tata surya untuk kelas VII SMP layak dan efektif digunakan dalam pembelajaran.

\section{DAFTAR PUSTAKA}

Agustanti, T. H. (2012). Implementasi metode inquiry untuk meningkatkan hasil belajar biologi. Jurnal Pendidikan IPA Indonesia, l(1), 16-20. https://doi.org/10.15294/jpii.v1i1.2007

Astuti, Y., \& Setiawan, B. (2013). Pengembangan lembar kerja siswa (LKS) berbasis pendekatan inkuiri terbimbing dalam pembelajaran kooperatif pada materi kalor. Jurnal Pendidikan IPA Indonesia, 2(1), 88-92. https://doi.org/10.15294/jpii.v2i1.2515

Dewantari, A. A. (2014). Sekilas tentang pop up, lift the flap, dan movable book. Retrieved from http://gi.or.id/read/observation/sekilastentang-pop-up-lift-the-flap-dan-movablebook.html

Dewi, N. L., Dantes, N., \& Sadia, I. W. (2013). Pengaruh model pembelajaran inkuiri terbimbing terhadap sikap ilmiah dan hasil belajar IPA. PENDASI: Jurnal

Pendidikan Dasar Indonesia, 3(1).

Retrieved from

http://pasca.undiksha.ac.id/e-

journal/index.php/jurnal_pendas/article/vi ew/512

Douglas, E. P., \& Chiu, C.-C. (2009). Use of guided inquiry as an active learning technique in engineering. In Proceedings of the Research in Engineering Education Symposium. Felder Maskell Polanco. Retrieved from https://pdfs.semanticscholar.org/f0d8/48fc elef4df6a86297583aa44085c01d9dde.pdf

Febrianto, M. F. M., Setiadarma, W., \& Aryanto, H. (2014). Penerapan media dalam bentuk pop up book pada pembelajaran unsur-unsur rupa untuk siswa kelas 2 SDNU Kanjeng Sepuh Sidayu Gresik. Jurnal Pendidikan Seni Rupa, 2(3), 146-153. Retrieved from http://jurnalmahasiswa.unesa.ac.id/index. $\mathrm{php} / \mathrm{va} /$ article/view/9888

Hawarya, Y., \& Warso, A. W. D. D. (2014). Pengembangan pop-up module pembelajaran biologi pada materi pencemaran dan pelestarian lingkungan untuk siswa SMA kelas X. JUPEMASIPBIO (Jurnal Penelitian Mahasiswa Pendidikan Biologi), 1(1), 139-143. Retrieved from http://jupemasipbio.uad.ac.id/wpcontent/uploads/2014/11/30.NP_11A08003_YULISNA-H.pdf

Ikhsan, M., Sutarno, S., \& Prayitno, B. A. (2016). Pengembangan modul berbasis inkuiri terbimbing pada materi sistem gerak manusia untuk meningkatkan hasil belajar siswa kelas XI MIA SMA Negeri 1 Wera Kabupaten Bima Nusa Tenggara Barat. Inkuiri: Jurnal Pendidikan IPA, 5(1), 133-142. Retrieved from http://jurnal.fkip.uns.ac.id/index.php/inkui ri/article/view/9245

Khoirotun, A., Fianto, A. Y. A., \& Riqqoh, A. K. (2014). Perancangan buku pop-up museum Sangiran sebagai media pembelajaran tentang peninggalan sejarah. Jurnal Desain Komunikasi Visual, 2(1), 134-141. Retrieved from http://jurnal.stikom.edu/index.php/ArtNou veau/article/view/385

Kuhlthau, C. C., Maniotes, L. K., \& Caspari, A. 
K. (2007). Guided inquiry: Learning in the 21st century. Libraries Unlimited.

Maharani, D. W., \& Dewi, N. R. (2015). The implementation of science inquiry-based website oriented by cultural deviance solution to instill students' character and independence. Jurnal Pendidikan IPA Indonesia, $4(1), \quad 25-30$. https://doi.org/10.15294/jpii.v4i1.3497

Margiastuti, S. N., Parmin, P., \& Pamelasari, S. D. (2015). Penerapan model guided inquiry terhadap sikap ilmiah dan pemahaman konsep siswa pada tema ekosistem. Unnes Science Education Journal, 4(3). https://doi.org/10.15294/USEJ.V4I3.8859

Matthew, B. M., \& Kenneth, I. O. (2013). A study on the effects of guided inquiry teaching method on students achievement in logic. International Researcher, 2(1), 135-140. Retrieved from http://iresearcher.org/133-140 BAKKE M.MATTHEW gambia.pdf

Muhafid, E. A., Dewi, N. R., \& Widiyatmoko, A. (2013). Pengembangan modul IPA terpadu berpendekatan keterampilan proses pada tema bunyi di SMP kelas VIII. Unnes Science Education Journal, 2(1), 140-148. https://doi.org/10.15294/USEJ.V2I1.1766

Parmin, P., \& Peniati, E. (2012). Pengembangan modul mata kuliah strategi belajar mengajar IPA berbasis hasil penelitian pembelajaran. Jurnal Pendidikan IPA Indonesia, $\quad 1(1), \quad 8-15$. https://doi.org/10.15294/jpii.vli1.2006

Prastowo, A. (2013). Pengembangan bahan ajar tematik tinjauan teoritis dan praktik. Yogyakarta: Diva Press.

Rahayu, K. D., Widiyatmoko, A., \& Dewi, N. R. (2016). Efektivitas model make a match berbasis guided inquiry tema ekosistem pada sikap ilmiah dan keterampilan proses sains siswa. Unnes Science Education Journal, 5(2), 1308-1320. Retrieved from https://journal.unnes.ac.id/sju/index.php/u sej/article/view/13154

Setyowati, R., Parmin, P., \& Widiyatmoko, A.
(2013). Pengembangan modul IPA berkarakter peduli lingkungan tema polusi sebagai bahan ajar siswa SMK N 11 Semarang. Unnes Science Education Journal, 2(2), 245-253. https://doi.org/10.15294/USEJ.V2I2.2031

Sugiyono. (2015). Metode penelitian pendidikan: Pendekatan kuantitatif, kualitatif, dan $R \& D$. Bandung: Alfabeta.

Suprihatin, E., \& Hidayah, Y. (2014). Penerapan model pembelajaran inkuiri terbimbing pada konsep pencemaran lingkungan dalam melatih keterampilan menyelesaikan masalah siswa kelas VII MTS At-Thohiriyah. Lentera Jurnal Ilmiah Kependidikan, 9(2). Retrieved from

http://ejurnal.stkipbjm.ac.id/index.php/jpl/ article/view $/ 43 / 0$

Trianto, T. (2007). Model-model pembelajaran inovatif berorientasi Konstruktivistik. Jakarta: Prestasi Pustaka.

Villagonzalo, E. C. (2014). Process oriented guided inquiry learning: An effective approach in enhancing students' academic performance. In The DLSU Research Congress (pp. 1-6). Manila: De La Salle University. Retrieved from https://pdfs.semanticscholar.org/6df4/19f5 8f5c2189dc0fb6267f1 fcbdb8dfd6a70.pdf

Wenning, C. J. (2011). The levels of inquiry model of science teaching. Journal of Physics Teacher Education Online, 6(2), 9-16.

Wulandari, W. (2015, September 8). Pengembangan modul berbentuk pop-up dan smash book materi sistem reproduksi manusia di SMA Kesatrian 1 Semarang. Universitas Negeri Semarang. Retrieved from http://lib.unnes.ac.id/22023/

Yusro, A. C., \& Sasono, M. (2016). Penggunaan modul ilustratif berbasis inkuiri terbimbing pokok bahasan kinematika gerak lurus untuk meningkatkan hasil belajar dan kemandirian siswa kelas VII SMPN 14 Madiun. Jurnal Pendidikan Fisika Dan Keilmuan (JPFK), 2(1), 2935. https://doi.org/10.25273/jpfk.v2i1.22 